\title{
BEKOORLIJKE EDUCATIE: \\ EEN INTERVIEW MET JAN MAARTEN BOLL
}

In de periode van 2010 tot 2013 was Jan Maarten Boll voorzitter van de Vereniging, een bestuursperiode waarin de viering van het 95-jarig bestaan in oktober 2013 zonder twijfel het hoogtepunt vormde. "Ik was gevraagd als buitenstaander", vertelt Boll, "de VVAK had een nieuwe impuls nodig en iemand van buiten kan daar makkelijker voor zorgen. Bovendien bood mijn ervaring bij de Vereniging Rembrandt me de gelegenheid een bijdrage aan het VVAK-bestuur te leveren." Een buitenstaander - slechts in zekere zin - dus, maar wel een buitenstaander die vanaf zijn jeugd naar kunst had gekeken, van jongs af aan had verzameld, iemand met een duidelijke visie op de wijze waarop kunst het best geapprecieerd kan worden en betekenis kan krijgen. Kunst lijkt een vaag en onbegrensd begrip, maar kenmerkend voor Jan Maarten Bolls belangstelling is juist die brede blik. "Ik zie het als een persoonlijke opdracht om de grote culturen te begrijpen.” Boll benadrukt geen kenner te zijn van de kunsten uit Azië maar affiniteit is er zeker, allereerst met de kunsten uit Japan en Perzië. "Ik ben eigenlijk een man van de schilderen tekenkunst, een liefhebber van de lijn. Ook van eigentijdse kunst, maar daarbinnen gaat het me om de voortzetting van een traditie in het heden."

Boll had er vertrouwen in een bijdrage aan de VVAK te kunnen leveren, maar zag ook in zijn toetreding tot het bestuur een mooie gelegenheid om te leren. "Ik wist natuurlijk dat de Vereniging en het Rijksmuseum Amsterdam een prachtige collectie hadden op het gebied van de Aziatische kunst. Daar een rol in te kunnen spelen, voelde als een voorrecht."

Uitgangspunt binnen de belangstelling voor de kunsten is, volgens Boll, de plicht je te ontwikkelen; overigens een genoeglijke verplichting. Je kunt pas echt van kunst genieten door je in te spannen, door je blik en geest te verruimen. "Bij het ouder worden wordt het moeilijker specifieke kennis te verwerven, maar visuele kennis opnemen is geen probleem.” Door jarenlang naar vele en uiteenlopende terreinen van de beeldende kunst te kijken is er een soort kapstok ontstaan waardoor beelden hun plaats krijgen, met elkaar verbonden kunnen worden en extra betekenis krijgen. "Het is als wandelen in Japan, met steeds andere visuele ervaringen en perspectieven, een steeds wisselende focus, een veelheid aan indrukken die elkaar versterken." Een visie waar optimisme uit spreekt: alles is te ontdekken.

\section{Het jubileum van de VVAK}

Het zijn omwegen die leiden tot een beter begrip en een betere appreciatie van kunstwerken, waar en wanneer ook gemaakt. Deze zoektocht en omwegen zijn heel duidelijk herkenbaar in het werk van Edmund de Waal en om die reden is de verwerving van An idea (for the journey) een fantastisch 
memento van het 95-jarig bestaan van de VVAK en is het Aziatisch Paviljoen precies de juiste plek om het te tonen.

De parallel tussen Boll en de oprichters van de VVAK is opvallend. Vanuit de belangstelling voor de eigentijdse kunst, een sterk ontwikkeld esthetisch oog, wordt de blik op Azië gericht. Ziet Boll dat ook zo? "De 19e eeuw duurde lang in Nederland. Het is opvallend hoe donker de Nederlandse schilderkunst uit die periode is. Daar komt pas verandering in als de blik naar buiten wordt gericht, ook op Azië. Het is begrijpelijk dat Westendorp en zijn geestverwanten de blik op Azië richtten. Ik ben inderdaad ook bijzonder geboeid door de vraag wat de contacten tussen Azië en Europa ons gebracht hebben, niet alleen ons hier in Europa, maar ook in Azië. Daarom heb ik me er in mijn bestuursperiode voor ingezet juist wel aandacht te schenken aan voorwerpen die ontstaan zijn in de interactie tussen Oost en West. Door te begrijpen hoe deze werelden elkaar raken en verrijken ontstaat een groter begrip voor kunst in het algemeen, voor de kunst uit Azië, voor de westerse kunst - niet alleen voor de evidente hybride werken die uit die ontmoeting van Oost en West zijn voortgekomen.

Het is een voor de hand liggende en tegelijk boeiende opdracht om bij het 100 -jarig bestaan van de Vereniging na te gaan wat er 100 jaar geleden voor Westendorp speelde - waarom Aziatische kunst? Op welke manier verzamelen? Op welke manier en met welke boodschap het publiek bereiken? En vervolgens na te gaan of deze kwesties nog steeds geldig zijn of misschien aanpassing behoeven."

\section{Educatie}

Eén aspect is volgens Boll cruciaal: educatie. De opdracht die hij voor zichzelf vanzelfsprekend acht - je zelf ontwikkelen - geldt evenzeer of misschien nog sterker voor een organisatie als de VVAK of het museum. Het is eigenlijk het $19^{\mathrm{e}}$-eeuwse ideaal van de volksverheffing, ooit universeel begrepen en door socialisme en liberalisme omarmd, en voor de $21^{\mathrm{e}}$ eeuw onverminderd relevant. "Het gaat er niet alleen om of iets wel of niet mooi is, het gaat ook om begrip. Het opwekken van begrip, het openen van de ogen, leren verschillen zien, te accepteren en respecteren. De boeddha's van Bamiyan waren niet verwoest als mensen dat hadden geleerd." En dus ligt er een verantwoordelijkheid bij organisaties als musea en de VVAK en ook bij particulieren om zich binnen een vereniging als de VVAK in te zetten. "Het genoegen dat ikzelf als liefhebber en verzamelaar aan kunst beleef, leidt tot een behoefte dit te delen met anderen. Je gunt dat anderen ook, sterker nog, je vindt dat ze er recht op hebben. Bekoorlijke educatie, dat is het."

Het museum moet een plek zijn waar mensen kennis kunnen opdoen, hun mening kunnen vormen, keuzes kunnen maken. Het is een plaats waar objecten en verhalen samenkomen. "Daar was steeds mijn visie op de functie van de VVAK: de bezoeker ziet dat het mooi is én leert, het gaat om kijken en leren." De VVAK had en heeft haar tijdschrift Aziatische Kunst dat op dit terrein van groot belang is. "Ik ben een groot bewonderaar van jullie", zegt Boll, "en ik zie het als belangrijke taak voor de VVAK en haar leden om jullie te steunen en te stimuleren. Het moeilijkste onderwerp tijdens mijn voorzitterschap heb ik gevonden het moeten terugbrengen om financiële redenen van het aantal uitgaven van Aziatische Kunst van vier naar drie

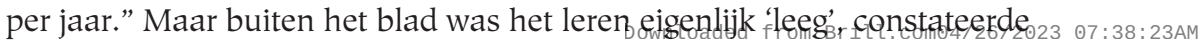


Boll. Met grote volharding werd gewerkt aan de hernieuwde invulling van de leerstoel. Met succes. Op 12 december 2014 sprak Anne Gerritsen haar oratie uit als bijzonder hoogleraar van de Kikkoman leerstoel voor de studie van de interculturele dynamiek van de Azië-Europa uitwisseling.

De aandacht voor de leerstoel en voor het leren in het algemeen heeft ook een praktische kant. De VVAK krijgt subsidie van de stad Amsterdam en de aanstelling van Anne Gerritsen en de overige educatieve activiteiten passen in de verplichting die de VVAK tegenover de gemeente dient te vervullen. "Die samenwerking met de universiteit biedt ook andere mogelijkheden", aldus Boll. Er ontstaat een groeiende postdoctorale markt: universiteiten bieden - om bij te verdienen - allerhande cursussen voor ouderen aan. Daar kan de VVAK met haar leerstoel wellicht een rol in spelen.

Cruciaal blijft de collectie van de Vereniging in het Rijksmuseum Amsterdam. "De voorwerpen staan centraal en de VVAK moet de conservatoren steunen in hun werk de voorwerpen te laten spreken. We moeten zorgen een sterkere partner te worden, met meer leden en meer geld. En dan steeds als dat nodig is zelfbewust uitleggen waarom we er zijn."

- Jan van Campen is conservator Aziatische exportkunst en Menno Fitski is conservator Oost-Aziatische Kunst, van het Rijksmuseum Amsterdam. Zij maken beiden deel uit van de redactie van het tijdschrift Aziatische Kunst.

* foto: Rijksmuseum Amsterdam, afdeling Beeld, René den Engelsman. 


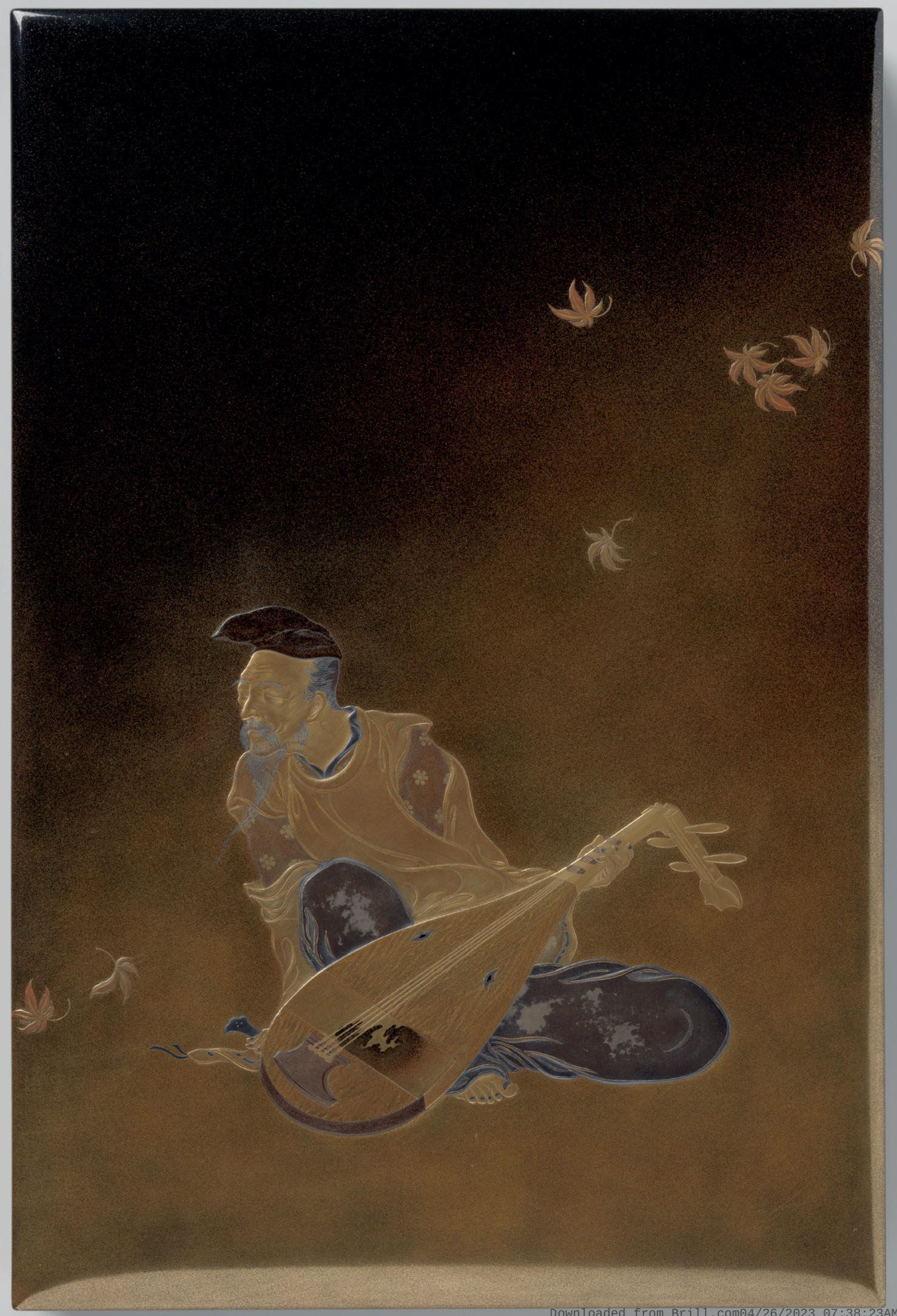

